\title{
MATERI MATEMATIKA YANG BELUM DIKUASAI SISWA: Analisis Hasil Ujian Nasional Paket A, B, dan C Tahun 2003/2004
}

Oleh: Safari *

\section{Abstrak}

Tujuan penelitian ini adalah untuk menjawab permasalahan berikut. Materi-materi mana yang belum dikuasai siswa pesersta ujian nasioal Paket A, B, dan C tahun 2003/2004 untuk mata pelajaran Matematika? Berdasarkan hasil analisis deskriptif dari 40 butir soal mata pelajaran Matematika yang masing-masing dijawab oleh peserta Paket $A=12855$ siswa, Paket $B=35497$ siswa, Paket C IPA= 413 siswa, maka diperoleh tiga hasil penelitian seperti berikut ini.

Pertama, penguasaan materi Matematika pada Paket $A$ yang kurang dari 50\% adalah 14 (35\%) materi, penguasaan materi 50\%-70\% adalah 16 (40\%) materi, dan penguasaan materi di atas $70 \%$ adalah 10 (25\%) materi. Kedua, penguasaan materi Matematika pada Paket B yang kurang dari 50\% adalah 11 (28\%) materi, penguasaan materi 50\%-70\% adalah 22 (55\%) materi, dan penguasaan materi di atas $70 \%$ adalah 7 (17\%) materi. Ketiga, penguasaan materi Matematika pada Paket $C$ IPA yang kurang dari $50 \%$ adalah 31 (77,5\%) materi, penguasaan materi $50 \%-70 \%$ adalah 9 (22,5\%) materi, dan penguasaan materi di atas $70 \%$ adalah 0 (0\%) materi. Untuk mengetahui nama-nama kemampuan/materi yang dimaksud, pembaca dapat membaca pada hasil penelitian ini. Selamat membaca!

*) Drs. Safari, M.A. adalah Ahli peneliti madya pada Pusat Penilaian Pendidikan, Balitbang Diknas, Jakarta 


\section{A. LATAR BELAKANG DAN MASALAH}

Ujian Nasional (UN) Paket A, B, dan C tahun 2003/2004 telah dilaksanakan di sebagian besar propinsi di Indonesia. Berdasarkan data dari Pusat Penilaian Pendidikan, Balitbang Diknas, khusus untuk mata pelajaran Matematika rata-rata nasional untuk Paket $\mathrm{A}$ adalah 5,79, Paket $B=5,25$, Paket $C$ IPA $=4,30$. Data ini memberi informasi kepada kita bahwa penguasaan materi peserta ujian nasional Paket A, B, dan C tahun 2003 terhadap mata pelajaran Matematika secara rata-rata nasional adalah kurang lebih $50 \%$ untuk Paket A dan B, sedangkan untuk Paket C lebih rendah yaitu $40 \%$ penguasaan materinya. Di samping itu, peserta tes secara nasional untuk Paket $A=12.855$ siswa yang lulus $10.965(85,30 \%)$ siswa yang tidak lulus $1890(14,70 \%)$ siswa, untuk Paket $B=35.497$ siswa yang lulus $30.338(85,47 \%)$ siswa yang tidak lulus 5159 (14,53\%), untuk Paket C IPA $=413$ siswa yang lulus $130(31,48 \%)$ siswa yang tidak lulus $283(68,52 \%)$ siswa. Informasi ini menunjukkan bahwa peserta ujian nasional yang tidak lulus untuk peserta tes Paket $\mathrm{A}$ dan B adalah 15\% dan untuk peserta Paket C IPA 69\%.

Berdasarkan informasi ini, penulis ingin melihat seberapa jauh para tutor/guru telah memaksimalkan kemampuan siswa terhadap materi/kompetensi yang UKRK khususnya pada mata pelajaran Matematika. UKRK adalah materi/kemampuan yang: Urgensi (wajib dikuasai siswa), Kontinuitas (merupakan kemampuan/materi lanjutan), Relevansi (manfaatnya terhadap mata pelajaran lain tinggi), Keterpakaian (keterpakaian dalam kehidupan sehari-hari tinggi). Mata pelajaran Matematika dan Sastra ini, tes/soalnya standard secara nasional karena soalnya disusun oleh pusat.

Seharusnya "setiap siswa/warga belajar berkemampuan maksimal/ tinggi terhadap materi yang diajarkan guru". Ini sering disebut dengan "belajar tuntas." Bila ada siswa yang berkemampuan menengah dan rendah, maka ini menjadi kewajiban guru untuk memaksimalkannya atau menuntaskannya. Penulis yakin, bila 
belajar tuntas dilaksanakan guru di sekolah, Insyaallah, para guru malu meluluskan anak didiknya dengan kriteria 5,01 melainkan 10,00. Karena nilai 50,1 menunjukkan belum tuntas materi yang dikuasainya.

Sekarang pertanyaannya adalah "Apakah siswa/warga belajar peserta ujian negara Paket A, B, dan C tahun 2003/2004 yang lalu sudah memenuhi syarat ketuntasan belajarnya untuk semua mata pelajaran?" Bila jawabannya sudah, siswa tidak akan mengalami kesulitan dalam menjawab pertanyaan UN karena peluang menjawab benar soal pasti tinggi. Bila jawabannya belum, siswa pasti akan mengalami kesulitan dalam menjawab pertanyaan UN karena peluang menjawab benar soal tergantung pada tingkat kemampuan siswanya. Bagaimana tingkat ketuntasan belajar siswa di setiap propinsi? Apakah mereka sama-sama tuntas atau sebaliknya? Sesuai dengan lingkup penelitian ini, "Apakah siswa peserta UN Paket A, B, dan C secara nasional sudah memenuhi ketuntasan belajarnya untuk mata pelajaran Matematika?"

Dalam ujian nasional Paket A tahun 2003, mata pelajaran Matematika terdiri dari 40 butir soal atau kompetensi/kemampuan yang diuji. Adapun kompetensi yang diujikan untuk 40 butir soal secara berurutan adalah: (1) mengubah ukuran jam ke menit atau sebaliknya, (2) menentukan hasil kali bilangan dua angka, (3) mengubah ukuran b erat ton ke kilogram, (4) menentukan FPB dari dua bilangan, (5) menentukan KPK dari dua bilangan, (6) menentukan hasil penjumlahan dua pecahan berpenyebut tidak sama, (7) menyelesaikan soal cerita yang mengandung penjumlahan dan pengurangan pecahan, (8) menghitung luas bangun datar, (9) menentukan hasil jumlah ukuran gros dan lusin, (10) menentukan hasil hitung campuran beberapa bilangan cacah, (11) menentukan bilangan kuadrat di antara bilangan yang disajikan, (12) menentukan hasil penarikan akar pangkat dua bilangan kuadrat, (13) mengubah pecahan biasa ke pecahan desimal atau sebaliknya, (14) menentukan hasil kali bilangan, (15) menentukan hasil pembagian suatu bilangan dengan bilangan lainnya, (16) 
menentukan hasil perjumlahan bilangan beberapa bilangan bulat, (17) menentukan luas gambar bangun gabungan, (18) menentukan hasil jumlah beberapa satuan waktu, (19) mengubah pecahan biasa ke pecahan campuran atau sebaliknya, (20) menjumlahkan 2 pecahan campuran, (21) menentukan hasil kali dua pecahan campuran, (22) menentukan gambar hasil percerminan, (23) menyelesaikan soal cerita mengenai pecahan desimal, (24) menentukan hasil jumlah 3 pecahan desimal, (25) menentukan hasil kali 3 pecahan desimal, (26) menentukan hasil pembagian tiga pecahan desimal, (27) menentukan volum balok, (28) menentukan bilangan kubik (pangkat tiga), (29) menentukan hasil akar pangkat tiga, (30) menentukan penyelesaian soal cerita mengenai perbandingan, (31) mengubah ukuran suhu dalam ${ }^{\circ} \mathrm{C},{ }^{0} \mathrm{~F}$, atau ${ }^{0} \mathrm{R}$, (32) menghitung keliling sebenarnya pada daerah berskala, (33) menghitung jarak sebenarnya antara 2 kota pada peta, (34) menentukan luas lingkaran yang diketahui diameternya, (35) menentukan luas sebenarnya suatu bidang datar pada peta berskala, (36) menentukan pasangan titik yang sesuai dengan persamaan, (37) menentukan hasil penjulahan dan pengurangan pecahan desimal, (38) menentukan hasil perkalian dan pembagian pecahan desimal, (39)menentukan rata-rata sekelompok data, (40) menentukan volum tabung.

Dalam ujian nasional Paket B tahun 2003, mata pelajaran Matematika terdiri dari 40 butir soal atau kompetensi/kemampuan yang diuji. Adapun kompetensi yang diujikan untuk 40 butir soal secara berurutan adalah: (1) menentukan KPK dua bilangan, (2) membandingkan dua bilangan bulat, (3) menentukan hasil penjumlahan bilangan bulat, (4) membandingkan dua pecahan, (5) menentukan hasil operasi hitung pada pecahan, (6) menentukan hasil operasi hitung pada pecahan, (7) menentukan harga pembelian, penjualan, untung, atau rugi, (8) menentukan harga pembelian, penjualan, untung, atau rugi, (9) menentukan harga pembelian, penjualan, untung, atau rugi, (10) menentukan harga pembelian, penjualan, untung, atau rugi, (11) menentukan harga pembelian, penjualan, untung, atau rugi, (12) menentukan keliling 
bangun datar, (13) menentukan banyak diagonal ruang dari bangun ruang, (14) menentukan jaring-jaring bangun ruang, (15) menentukan jenis segitiga, (16) menentukan jenis segitiga, (17) menentukan sifat dan luas bangun datar, (18) menentukan sifat dan luas bangun datar, (19) menentukan sifat dan luas bangun datar, (20) menentukan sifat dan luas bangun datar, (21) menentukan haisl perbandingan senilai dan berbalik nilai, (22) menentukan hasil perbandingan senilai dan berbalik nilai, (23) menentukan jarak, waktu, atau kecepatan, (24) menentukan jarak, waktu, atau kecepatan, (25) menentukan keliling dan luas lingkaran, (26) menentukan keliling dan luas lingkaran, (27) menentukan populasi dan sampel penelitian, (28) menentukan populasi dan sampel penelitian, (29) menentukan rata-rata dan median dari sekelompok data, (30) menentukan rata-rata dan median dari sekelompok data, (31) menentukan sisi, luas permukaan, dan volum bangun ruang, (32) menentukan sisi, luas permukaan, dan volum bangun ruang, (33) menentukan sisi, luas permukaan, dan volum bangun ruang, (34) menentukan sisi, luas permukaan, dan volum bangun ruang, (35) menentukan sisi, luas permukaan, dan volum bangun ruang, (36) menentukan sisi, luas permukaan, dan volum bangun ruang, (37) menentukan bayangan oleh suatu transformasi, (38) menentukan bayangan oleh suatu transformasi, (39) menentukan bayangan oleh suatu transformasi, (40) menentukan hasil perbandingan senilai dan berbalik nilai.

Dalam ujian nasional Paket C (IPA) tahun 2003, mata pelajaran Matematika terdiri dari 40 butir soal atau kompetensi/kemampuan yang diuji. Adapun kompetensi yang diujikan untuk 40 butir soal secara berurutan adalah: (1) memahami bentuk akar dan operasinya, (2) menyelesaikan soal permasalahan persamaan kuadrat, (3) menyelesaikan soal permasalahan persamaan kuadrat, (4) memahami sudut-sudut yang berelasi pada trigonometri, (5) menyelesaikan sistem persamaan linier 2 variabel dan 3 variabel, (6) menyelesaikan sistem persamaan linier 2 variabel dan 3 variabel, (7) memenuhi matriks dan permasalahannya, (8) memenuhi matriks dan permasalahannya, (9) menyelesaikan soal barisan dan deret 
aritmetika maupun geomatika, (10) menyelesaikan soal barisan dan deret aritmetika maupun geomatika, (11) menyelesaikan soal barisan dan deret aritmetika maupun geomatika, (12) memahami masalah permutasi dan kombinasi, (13) menyelesaikan soal statistik, (14) menyelesaikan soal jumlah dan selisih dua sudut dalam trigonometri, (15) memahami konsep komposisi fungsi, (16) memeahami konsep invers fungsi, (17) menyelesaikan soal limit, (18) menyelesaikan soal limit, (19) menyelesaikan soal-soal deferensial, (20) menyelesaikan soal-soal deferensial, (21) menyelesaikan soal-soal deferensial, (22) menyelesaikan soal-soal deferensial, (23) menyelesaikan persoalan persamaan eksponen, (24) memahami dan menyelesaikan soal-soal logaritma, (25) menelesaikan soal program linier dan menerapkan dalam kehidupan, (26) memahami menerapkan konsep sudut antara 2 vektor, (27) memahami dan menerapkan konsep proyeksi vektor, (28) memahami konsep-konsep lingkaran dan sifat-sifatnya dalam penerapan, (29) memahami konsep-konsep parabola dan menerapkan dalam soal, (30) menyeleksi soal-soal persamaan trigonometri, (31) menyeleksi soal-soal persamaan trigonometri, (32) konsep-konsep suku terbanyak dan teorema sisa dan menyelesaikan dalam soal, (33) memahami konsep-konsep suku banyak dan teorema faktor, (34) memahami dan menerapkan konsep-konsep integral dalam soal, (35) memahami dan menerapkan konsep-konsep integral dalam soal, (36) memahami dan menerapkan konsep-konsep integral dalam soal, (37) memahami dan menerapkan konsep-konsep integral dalam soal, (38) memahami dan menerapkan konsep-konsep dimensi tiga, (39) memahami konsep-konsep transformasi, (40) menyelesaikan masalah logika dalam penerapan dikehidupan.

Dari berbagai uraian di atas muncullah permasalahan dalam penelitian ini, yaitu materi-materi mana yang belum dikuasai siswa/ warga belajar peserta ujian nasional Paket A, B, dan C Tahun 2003/ 2004 pada mata pelajaran Matematika? Oleh karena itu, permasalahan ini merupakan tujuan utama dalam penelitian ini. 


\section{B. METODE PENELITIAN}

Subjek penelitian ini adalah butir-butir soal Matematika yang

\begin{tabular}{|c|c|c|c|c|}
\hline No & Propinsi/Negara & $\begin{array}{l}\text { Paket A } \\
\text { (siswa) }\end{array}$ & $\begin{array}{l}\text { Paket B } \\
\text { (siswa) }\end{array}$ & $\begin{array}{c}\text { Paket C } \\
\text { IPA (siswa) }\end{array}$ \\
\hline 1. & NAD & 201 & 755 & 149 \\
\hline 2. & Sumut & 364 & 852 & - \\
\hline 3. & Sumbar & 279 & 524 & - \\
\hline 4. & Riau & 29 & 578 & - \\
\hline 5. & Jambi & 406 & 244 & - \\
\hline 6. & Sumsel & 1200 & 1703 & - \\
\hline 7. & Bengkulu & 15 & 658 & - \\
\hline 8. & Lampung & 16 & 139 & - \\
\hline 9. & DKI & 556 & 1614 & 81 \\
\hline 10. & Jabar & 611 & 5962 & 106 \\
\hline 11. & Jateng & 87 & 2486 & - \\
\hline 12. & DIY & 504 & 88 & - \\
\hline 13. & Jatim & 1171 & 6616 & 7 \\
\hline 14. & Bali & 841 & 187 & - \\
\hline 15. & NTB & 800 & 1465 & - \\
\hline 16. & NTT & 1447 & 644 & - \\
\hline 17. & Kalbar & 489 & 1301 & - \\
\hline 18. & Kalteng & - & 274 & 31 \\
\hline 19. & Kaltim & 109 & 172 & 6 \\
\hline 20. & Kalsel & 340 & 474 & - \\
\hline 21. & Sulut & 35 & 270 & - \\
\hline 22. & Sulteng & - & 264 & - \\
\hline 23. & Sultra & 119 & 750 & - \\
\hline 24. & Sulsel & 500 & 656 & - \\
\hline 25. & Maluku & 291 & 754 & - \\
\hline 26. & Maluku Utara & 1183 & 2534 & - \\
\hline 27. & Papua & 161 & 515 & - \\
\hline 28. & Banten & 947 & 2382 & 7 \\
\hline 29. & Gorontalo & 39 & 52 & 26 \\
\hline 30. & Babel & 115 & 583 & - \\
\hline \multirow[t]{2}{*}{31.} & Riyadh, SaudiArabia & - & 1 & - \\
\hline & Jumlah & 12855 & 35497 & 413 \\
\hline
\end{tabular}

Sumber: Puspendik Balitbang Diknas, 2004 
digunakan dalam Ujian Nasional Tahun 2003/2004 pada peserta ujian Paket A, B, dan Paket C IPA. Adapun jumlah peserta tesnya secara rinci dapat dilihat pada Tabel 1.

\section{Tabel 1}

Peserta Ujian Nasional Paket A, B, dan C Tahun 2003/2004 Instrumen yang dipergunakan dalam penelitian ini adalah data hasil UN Paket A, B, C tahun pelajaran 2003-2004 untuk mata pelajaran Matematika. Tes ini terdiri dari 40 butir soal atau kompetensi/ kemampuan yang diuji.

Metode analisis yang dipergunakan untuk menjawab tujuan penelitian ini adalah analisis deskriptif dengan mempergunakan program SPSS 12.00 for Window. Setiap butir soal dihitung proporsi siswa yang menjawab benar soal. Kemudian setiap butir soal dikelompokkan menjadi 3 kriteria, yaitu (1) kelompok proporsi $<50 \%$ (00,00 - 50,00), (2) kelompok proporsi 50\% - 70\% (50,01-70,00),

(3) kelompok proporsi $>70 \%(70,01-100)$.

\section{HASIL PENELITIAN DAN PEMBAHASAN}

\section{Materi Matematika pada Paket A}

Hasil analisis dari 40 butir soal tes Matematika yang dikerjakan oleh 12.855 siswa/peserta Ujian Nasional Paket A dari 28 propinsi menunjukkan bahwa penguasaan materi Matematika yang kurang dari $50 \%$ adalah $14(35 \%)$ materi, penguasaan materi $50 \%-70 \%$ adalah 16 (40\%) materi, dan penguasaan materi

\begin{tabular}{|c|l|l|l|}
\hline Materi/Soal & $<50 \%$ & $50 \%-70 \%$ & $>70 \%$ \\
\hline \multirow{3}{*}{ Nomor soal } & $3,9,14,18,19$, & $4,6,8,12,13,15$, & $1,2,5,7,10,11$, \\
& $21,22,23,24$, & $17,20,28,29,31$, & $16,26,30,40$ \\
& $25,27,32,33$ & $34,35,36,3739$ & \\
\hline Jumlah & $14(35 \%)$ & $16(40 \%)$ & $10(25 \%)$ \\
\hline
\end{tabular}


di atas $70 \%$ adalah 10 (25\%) materi. Data selengkapnya dapat dilihat pada Tabel 2.

\section{Tabel 2}

Persentase kemampuan siswa peserta Ujian Nasional Paket A Tahun 2003/2004 pada 40 butir soal/materi dalam ujian mata pelajaran Matematika

Tabel 2 menunjukkan bahwa materi Matematika pada Ujian Nasional Paket A tahun 2003/2004 yang telah dikuasai siswa $50 \%-70 \%$ adalah lebih banyak yaitu 16 (40\%) materi dibandingkan dengan materi yang telah dikuasai 70\%-100\% (10 atau $25 \%$ materi) dan $<50 \%$ (14 atau 35\% materi).

Kemampuan/materi yang belum dikuasai siswa $(<50 \%)$ adalah kemampuan/materi nomor: (3) mengubah ukuran b erat ton ke kilogram, (9) menentukan hasil jumlah ukuran gros dan lusin, (14) menentukan hasil kali bilangan, (18) menentukan hasil jumlah beberapa satuan waktu, (19) mengubah pecahan biasa ke pecahan campuran atau sebaliknya, (21) menentukan hasil kali dua pecahan campuran, (22) menentukan gambar hasil percerminan, (23) menyelesaikan soal cerita mengenai pecahan desimal, (24) menentukan hasil jumlah 3 pecahan desimal, (25) menentukan hasil kali 3 pecahan desimal, (27) menentukan volum balok, (32) menghitung keliling sebenarnya pada daerah berskala, (33) menghitung jarak sebenarnya antara 2 kota pada peta.

Kemampuan/materi yang telah dikuasai siswa 50\%-70\% adalah kemampuan/materi nomor: (4) menentukan FPB dari dua bilangan, (6) menentukan hasil penjumlahan dua pecahan berpenyebut tidak sama, (8) menghitung luas bangun datar, (12) menentukan hasil penarikan akar pangkat dua bilangan kuadrat, (13) mengubah pecahan biasa ke pecahan desimal atau sebaliknya, (15) menentukan hasil pembagian suatu bilangan dengan bilangan lainnya, (17) menentukan luas gambar bangun gabungan, (20) menjumlahkan 2 pecahan campuran, 
(28) menentukan bilangan kubik (pangkat tiga), (29) menentukan hasil akar pangkat tiga, (31) mengubah ukuran suhu dalam ${ }^{\circ} \mathrm{C}$, ${ }^{0} \mathrm{~F}$, atau ${ }^{\circ} \mathrm{R}$, (34) menentukan luas lingkaran yang diketahui diameternya, (35) menentukan luas sebenarnya suatu bidang datar pada peta berskala, (36) menentukan pasangan titik yang sesuai dengan persamaan, (37) menentukan hasil penjulahan dan pengurangan pecahan desimal, (39)menentukan rata-rata sekelompok data.

Kemampuan/materi yang sudah dikuasai siswa (70\%-100\%) adalah kemampuan/materi nomor: (1) mengubah ukuran jam ke menit atau sebaliknya, (2) menentukan hasil kali bilangan dua angka, (5) menentukan KPK dari dua bilangan, (7) menyelesaikan soal cerita yang mengandung penjumlahan dan pengurangan pecahan, (10) menentukan hasil hitung campuran beberapa bilangan cacah, (11) menentukan bilangan kuadrat di antara bilangan yang disajikan, (16) menentukan hasil perjumlahan bilangan beberapa bilangan bulat, (26) menentukan hasil pembagian tiga pecahan desimal, (30) menentukan penyelesaian soal cerita mengenai perbandingan, (40) menentukan volum tabung.

\section{Materi Matematika pada Paket B}

Hasil analisis dari 40 butir soal tes Matematika yang dikerjakan oleh 35.497 siswa/peserta Ujian Nasional Paket B dari 30 propinsi dan 1 negara Riyadh, Saudi Arabia menunjukkan bahwa

\begin{tabular}{|c|l|l|l|}
\hline Materi/Soal & \multicolumn{1}{|c|}{$<50 \%$} & $50 \%-70 \%$ & $>70 \%$ \\
\hline \multirow{3}{*}{ Nomor soal } & $2,19,20,22,26$, & $1,3,6,7,8,10,11$, & $4,5,9,12$, \\
& $27,31,33,35$, & $14,15,18,21,23$, & $13,16,17$ \\
& 38,40 & $\begin{array}{l}24,25,28,29,30, \\
32,34,36,37,39\end{array}$ & \\
\hline Jumlah & $11(28 \%)$ & $22(55 \%)$ & $7(17 \%)$ \\
\hline
\end{tabular}


penguasaan materi Matematika yang kurang dari 50\% adalah $11(28 \%)$ materi, penguasaan materi 50\%-70\% adalah $22(55 \%)$ materi, dan penguasaan materi di atas $70 \%$ adalah 7 (17\%) materi. Data selengkapnya dapat dilihat pada Tabel 3.

\section{Tabel 3}

Persentase kemampuan siswa peserta Ujian Nasional Paket B Tahun 2003/2004 pada 40 butir soal/materi dalam ujian mata pelajaran Matematika

Tabel 3 menunjukkan bahwa materi Matematika pada Ujian Nasional Paket B tahun 2003/2004 yang telah dikuasai siswa $50 \%-70 \%$ adalah lebih banyak yaitu 22 (55\%) materi dibandingkan dengan materi yang telah dikuasai 70\%-100\% (7 atau $17 \%$ materi) dan $<50 \%$ (11 atau $28 \%$ materi).

Kemampuan/materi yang belum dikuasai siswa $(<50 \%)$ adalah kemampuan/materi nomor: (2) membandingkan dua bilangan bulat, (19) menentukan sifat dan luas bangun datar, (20) menentukan sifat dan luas bangun datar, (22) menentukan hasil perbandingan senilai dan berbalik nilai, (26) menentukan keliling dan luas lingkaran, (27) menentukan populasi dan sampel penelitian, (31) menentukan sisi, luas permukaan, dan volum bangun ruang, (33) menentukan sisi, luas permukaan, dan volum bangun ruang, (35) menentukan sisi, luas permukaan, dan volum bangun ruang, (38) menentukan bayangan oleh suatu transformasi, (40) menentukan hasil perbandingan senilai dan berbalik nilai.

Kemampuan/materi yang telah dikuasai siswa 50\%-70\% adalah kemampuan/materi nomor: (1) menentukan KPK dua bilangan, (3) menentukan hasil penjumlahan bilangan bulat, (6) menentukan hasil operasi hitung pada pecahan, (7) menentukan harga pembelian, penjualan, untung, atau rugi, (8) menentukan harga pembelian, penjualan, untung, atau rugi, (10) menentukan harga pembelian, penjualan, untung, atau rugi, (11) menentukan harga pembelian, penjualan, untung, atau rugi, (14) menentukan 
jaring-jaring bangun ruang, (15) menentukan jenis segitiga, (18) menentukan sifat dan luas bangun datar, (21) menentukan haisl perbandingan senilai dan berbalik nilai, (23) menentukan jarak, waktu, atau kecepatan, (24) menentukan jarak, waktu, atau kecepatan, (25) menentukan keliling dan luas lingkaran, (28) menentukan populasi dan sampel penelitian, (29) menentukan rata-rata dan median dari sekelompok data, (30) menentukan rata-rata dan median dari sekelompok data, (32) menentukan sisi, luas permukaan, dan volum bangun ruang, (34) menentukan sisi, luas permukaan, dan volum bangun ruang, (36) menentukan sisi, luas permukaan, dan volum bangun ruang, (37) menentukan bayangan oleh suatu transformasi, (39) menentukan bayangan oleh suatu transformasi.

Kemampuan/materi yang sudah dikuasai siswa (70\%-100\%) adalah kemampuan/materi nomor: (4) membandingkan dua pecahan, (5) menentukan hasil operasi hitung pada pecahan, (9) menentukan harga pembelian, penjualan, untung, atau rugi, (12) menentukan keliling bangun datar, (13) menentukan banyak diagonal ruang dari bangun ruang, (16) menentukan jenis segitiga, (17) menentukan sifat dan luas bangun datar.

\section{Materi Matematika pada Paket C IPA}

Hasil analisis dari 40 butir soal tes Matematika yang dikerjakan oleh 413 siswa IPA dan 59.713 siswa IPS peserta Ujian Nasional Paket $C$ dari 8 propinsi (IPA) menunjukkan bahwa penguasaan

\begin{tabular}{|c|c|c|c|}
\hline Materi/Soal & $<50 \%$ & $50 \%-70 \%$ & $>70 \%$ \\
\hline Nomor soal & \begin{tabular}{|}
$3,4,6,9,10,11,12,13$ \\
$14,15,16,17,18,19$ \\
$20,21,26,27,28,29$ \\
$30,31,32,33,34,35$ \\
$36,37,38,39,40$
\end{tabular} & $\begin{array}{l}1,2,5,7,8 \\
22,23,24,25\end{array}$ & - \\
\hline Jumlah & $31(77,5 \%)$ & $9(22,5 \%)$ & $0(0 \%)$ \\
\hline
\end{tabular}


materi Matematika yang kurang dari 50\% adalah $31(77,5 \%)$, penguasaan materi $50 \%-70 \%$ adalah $9(22,5 \%)$, dan penguasaan materi di atas $70 \%$ adalah $0(0 \%)$. Data selengkapnya dapat dilihat pada Tabel 4.

\section{Tabel 4}

Persentase kemampuan siswa peserta Ujian Nasional Paket C IPA Tahun 2003/2004 pada 40 butir soal/materi dalam ujian mata pelajaran Matematika

Tabel 4 menunjukkan bahwa materi Matematika pada Ujian Nasional Paket C tahun 2003/2004 yang telah dikuasai siswa $<50 \%$ adalah lebih banyak yaitu $31(77,5 \%)$ materi dibandingkan dengan materi yang telah dikuasai $50 \%-70 \%$ (9 atau 22,5\% materi) dan $>70 \%$ ( 0 atau $0 \%$ materi).

Kemampuan/materi yang belum dikuasai siswa $(<50 \%)$ untuk siswa IPA adalah kemampuan/materi nomor: (3) menyelesaikan soal permasalahan persamaan kuadrat, (4) memahami sudutsudut yang berelasi pada trigonometri, (6) menyelesaikan sistem persamaan linier 2 variabel dan 3 variabel, (9) menyelesaikan soal barisan dan deret aritmetika maupun geomatika, (10) menyelesaikan soal barisan dan deret aritmetika maupun geomatika, (11) menyelesaikan soal barisan dan deret aritmetika maupun geomatika, (12) memahami masalah permutasi dan kombinasi, (13) menyelesaikan soal statistik, (14) menyelesaikan soal jumlah dan selisih dua sudut dalam trigonometri, (15) memahami konsep komposisi fungsi, (16) memeahami konsep invers fungsi, (17) menyelesaikan soal limit, (18) menyelesaikan soal limit, (19) menyelesaikan soal-soal deferensial, (20) menyelesaikan soal-soal deferensial, (21) menyelesaikan soal-soal deferensial, (26) memahami menerapkan konsep sudut antara 2 vektor, (27) memahami dan menerapkan konsep proyeksi vektor, (28) memahami konsepkonsep lingkaran dan sifat-sifatnya dalam penerapan, (29) 
memahami konsep-konsep parabola dan menerapkan dalam soal, (30) menyeleksi soal-soal persamaan trigonometri, (31) menyeleksi soal-soal persamaan trigonometri, (32) konsepkonsep suku terbanyak dan teorema sisa dan menyelesaikan dalam soal, (33) memahami konsep-konsep suku banyak dan teorema faktor, (34) memahami dan menerapkan konsepkonsep integral dalam soal, (35) memahami dan menerapkan konsep-konsep integral dalam soal, (36) memahami dan menerapkan konsep-konsep integral dalam soal, (37) memahami dan menerapkan konsep-konsep integral dalam soal, (38) memahami dan menerapkan konsep-konsep dimensi tiga, (39) memahami konsep-konsep transformasi, (40) menyelesaikan masalah logika dalam penerapan dikehidupan.

Kemampuan/materi yang telah dikuasai siswa 50\%-70\% untuk siswa IPA adalah kemampuan/materi nomor: (1) memahami bentuk akar dan operasinya, (2) menyelesaikan soal permasalahan persamaan kuadrat, (5) menyelesaikan sistem persamaan linier 2 variabel dan 3 variabel, (7) memenuhi matriks dan permasalahannya, (8) memenuhi matriks dan permasalahannya, (22) menyelesaikan soal-soal deferensial, (23) menyelesaikan persoalan persamaan eksponen, (24) memahami dan menyelesaikan soal-soal logaritma, (25) menelesaikan soal program linier dan menerapkan dalam kehidupan.

Kemampuan/materi yang sudah dikuasai siswa (70\%-100\%) untuk siswa IPA adalah tidak ada.

\section{KESIMPULAN DAN SARAN}

Berdasarkan analisis data di atas, penelitian ini menghasilkan halhal penting berikut ini. Berdasarkan hasil analisis deskriptif dari 40 butir soal mata pelajaran Matematika yang masing-masing diujikan kepada peserta Paket $A=12855$ siswa, Paket $B=35497$ siswa, Paket $C$ IPA $=413$ siswa, maka diperoleh tiga hasil penelitian seperti berikut ini. 
Pertama, penguasaan materi Matematika pada Paket A yang kurang dari 50\% adalah 14 (35\%) materi, penguasaan materi 50\%-70\% adalah 16 (40\%) materi, dan penguasaan materi di atas $70 \%$ adalah $10(25 \%)$ materi. Artinya bahwa materi Matematika pada Ujian Nasional Paket A tahun 2003/2004 yang telah dikuasai siswa 50\%$70 \%$ adalah lebih banyak yaitu $16(40 \%)$ materi dibandingkan dengan materi yang telah dikuasai 70\%-100\% (10 atau 25\% materi) dan $<50 \%$ (14 atau 35\% materi). Adapun kemampuan/materi yang belum dikuasai siswa $(<50 \%)$ adalah kemampuan/materi nomor: (3) mengubah ukuran berat ton ke kilogram, (9) menentukan hasil jumlah ukuran gros dan lusin, (14) menentukan hasil kali bilangan, (18) menentukan hasil jumlah beberapa satuan waktu, (19) mengubah pecahan biasa ke pecahan campuran atau sebaliknya, (21) menentukan hasil kali dua pecahan campuran, (22) menentukan gambar hasil percerminan, (23) menyelesaikan soal cerita mengenai pecahan desimal, (24) menentukan hasil jumlah 3 pecahan desimal, (25) menentukan hasil kali 3 pecahan desimal, (27) menentukan volum balok, (32) menghitung keliling sebenarnya pada daerah berskala, (33) menghitung jarak sebenarnya antara 2 kota pada peta.

Kedua, penguasaan materi Matematika pada Paket $B$ yang kurang dari 50\% adalah $11(28 \%)$ materi, penguasaan materi 50\%-70\% adalah 22 (55\%) materi, dan penguasaan materi di atas $70 \%$ adalah $7(17 \%)$ materi. Artinya bahwa materi Matematika pada Ujian Nasional Paket B tahun 2003/2004 yang telah dikuasai siswa 50\%$70 \%$ adalah lebih banyak yaitu $22(55 \%)$ materi dibandingkan dengan materi yang telah dikuasai $70 \%-100 \%$ (7 atau 17\% materi) dan $<50 \%$ (11 atau 28\% materi). Kemampuan/materi yang belum dikuasai siswa $(<50 \%)$ adalah kemampuan/materi nomor: (2) membandingkan dua bilangan bulat, (19) menentukan sifat dan luas bangun datar, (20) menentukan sifat dan luas bangun datar, (22) menentukan hasil perbandingan senilai dan berbalik nilai, (26) menentukan keliling dan luas lingkaran, (27) menentukan populasi dan sampel penelitian, (31) menentukan sisi, luas permukaan, dan 
volum bangun ruang, (33) menentukan sisi, luas permukaan, dan volum bangun ruang, (35) menentukan sisi, luas permukaan, dan volum bangun ruang, (38) menentukan bayangan oleh suatu transformasi, (40) menentukan hasil perbandingan senilai dan berbalik nilai.

Ketiga, penguasaan materi Matematika pada Paket $\mathrm{C}$ yang kurang dari $50 \%$ adalah 31 (77,5\%), penguasaan materi $50 \%-70 \%$ adalah $9(22,5 \%)$, dan penguasaan materi di atas $70 \%$ adalah $0(0 \%)$. Artinya bahwa materi Matematika pada Ujian Nasional Paket $\mathrm{C}$ tahun $2003 / 2004$ yang telah dikuasai siswa $<50 \%$ adalah lebih banyak yaitu $31(77,5 \%)$ materi dibandingkan dengan materi yang telah dikuasai 50\%-70\% (9 atau 22,5\% materi) dan $>70 \%$ (0 atau $0 \%$ materi). Kemampuan/materi yang belum dikuasai siswa $(<50 \%)$ untuk siswa IPA adalah kemampuan/materi nomor: (3) menyelesaikan soal permasalahan persamaan kuadrat, (4) memahami sudut-sudut yang berelasi pada trigonometri, (6) menyelesaikan sistem persamaan linier 2 variabel dan 3 variabel, (9) menyelesaikan soal barisan dan deret aritmetika maupun geomatika, (10) menyelesaikan soal barisan dan deret aritmetika maupun geomatika, (11) menyelesaikan soal barisan dan deret aritmetika maupun geomatika, (12) memahami masalah permutasi dan kombinasi, (13) menyelesaikan soal statistik, (14) menyelesaikan soal jumlah dan selisih dua sudut dalam trigonometri, (15) memahami konsep komposisi fungsi, (16) memeahami konsep invers fungsi, (17) menyelesaikan soal limit, (18) menyelesaikan soal limit, (19) menyelesaikan soal-soal deferensial, (20) menyelesaikan soal-soal deferensial, (21) menyelesaikan soal-soal deferensial, (26) memahami menerapkan konsep sudut antara 2 vektor, (27) memahami dan menerapkan konsep proyeksi vektor, (28) memahami konsep-konsep lingkaran dan sifat-sifatnya dalam penerapan, (29) memahami konsep-konsep parabola dan menerapkan dalam soal, (30) menyeleksi soal-soal persamaan trigonometri, (31) menyeleksi soal-soal persamaan trigonometri, (32) konsep-konsep suku terbanyak dan teorema sisa dan menyelesaikan dalam soal, (33) memahami konsep-konsep suku 
banyak dan teorema faktor, (34) memahami dan menerapkan konsep-konsep integral dalam soal, (35) memahami dan menerapkan konsep-konsep integral dalam soal, (36) memahami dan menerapkan konsep-konsep integral dalam soal, (37) memahami dan menerapkan konsep-konsep integral dalam soal, (38) memahami dan menerapkan konsep-konsep dimensi tiga, (39) memahami konsep-konsep transformasi, (40) menyelesaikan masalah logika dalam penerapan dikehidupan.

Berdasarkan ketiga hasil penelitian di atas, maka sebagai penutup penelitian ini ada dua saran penting seperti berikut ini. Pertama, kepada guru khususnya guru atau tutor Paket $A, B$, dan $C$ yang mengajar mata pelajaran Matematika perlu memaksimalkan kemampuan siswanya terhadap kemampuan/materi yang kurang di atas. Kedua, kepada siswa atau calon peserta ujian nasional Paket A, B, dan $C$ yang sedang mempersiapkan ujian sumatif perlu menguasai semua kompetensi/materi dalam mata pelajaran Matematika, khususnya pada kemampuan/materi-materi sulit menurut kakak kelasmu dalam penelitian ini. Selamat belajar!

\section{DAFTAR PUSTAKA}

Devito, Affred. (1990). Creative Wellstrings for Science Teaching. (Second Edition). USA.

Ebel, Robert L. and Frisbie, David A. (1991). Essentials of Educational Measurement. New Jersey: Prentice Hall.

Gonczi, Andrew (Editor). (1992). Developing a Competent Workforce. Adelaide: National Centre for Vocational Education Research Ltd. Haladyna, Thomas M. (1994). Developing and Validating Multiple-choice Test Items. New Jersey: Lawrence Erlbaum Associates, Publisher. Heaton, J.B. (1990). Classroom Testing. London: Longman.

Holland, P.W. \& Thayer, D.T. (1988). Test Validity. New Jersey: Lawrence Erlbaum Associates, Publishers.

Linn, Robert L. and Gronlund, Norman E. (1995). Measurement and Assessment in Teaching. (Seventh Edition). Ohio: Prentice-Hall, Inc. 
Lord, F.M. (1952). A Theory of Test Scores. USA: Educational Testing Service.

Marzano, Robert J. et al. (1988). Demensions of Thingking: A Framework for Curriculum and Instruction. Virginia: Association for Supervision and Curriculum Development.

Messick, Samuel. (1993). "Validity," Educational Measurement, Third Edition, ed. Robert L. Linn. New York: American Council on Education and Macmillan Publishing Company, A Division of Macmillan, Inc.

Millman, Jason and Arter, Judith A. Issues in Item Banking. In Journal of Educational Measurement, Volume 21, No. 4, Winter 1984, p. 315.

Millman, Jason and Greene, Jennifer. (1993). The Specification and Development of Tests of Achievement and Ability. In Educational Measurement. Third Edition. Edited by Robert L. Linn. Phoenix: American Council on Education, Series on Higher Education, Oryx Press.

Mueller, Daniel J. (1986). Measuring Social Attitudes: A Handbook for Researchers and Practitioners. New York: Teacher College, Columbia University.

Nitko, Anthony J. (1996). Educational Assessment of Students, Second Edition. Ohio: Merril, an imprin of Perntice Hall.

Oosterhof, Albert C. (1990). Classroom Applications of Educational Measurement. Ohio: Merrill Publishing Company.

Popham, W. James. (1995). Classroom Assessment: What Teachers Need to Know. Boston: Allyn and Bacon.

Pusat Penelitian dan Pengembangan Sistem Pengujian, Balitbang Dikbud. (1993/1994). Bahan Penataran Pengujian Pendidikan. Jakarta.

Raths, L. E. et al. (1996). Value and Teaching: Working with Value in Classroom . Clumbus: Charles E. Merill Publishing, Co.

Safari. (2000). Kaidah Bahasa Indonesia dalam Penulisan Soal. Jakarta: PT Kartanegara.

Stufflebeam, Daniel L. et al. (1971). Educational Evaluation and Decision Making. Illinois: F. E. Peacock Publishers, Inc.

Tinkelman, S.N. (1971). Planning the Objective Test. Educational Measurement (Second Ed.). Washington D.C.: American Countcil on Education. 